УДК : 327.82

\section{ДИПЛОМАТІЯ ПІД ЧАС ПАНДЕМІЇ COVID-19: ЇЇ РОЛЬ ТА НАСЛІДКИ У СФЕРІ ДИПЛОМАТІЇ ТА МІЖНАРОДНИХ ВІДНОСИН}

\section{Шевель Інна Петрівна}

кандидат соціологічних наук, доцент,

Київський національний університет культури і мистецтв, м.Київ, Україна

ORCID 0000-0002-6387-2506

shevelinna@ukr.net
Надіслано: 14.10.2020

Рецензовано:

30.10 .2020

Прийнято:

06.11 .2020

«Я бачу, що партнерство між США та Україною зміцнюється щодня, навіть у розпал цієї страшної пандемії»

(Тимчасова повірена в справах Сполучених Штатів Америки в Україні Крістіна Квін)

Стаття присвячена пандемії, яка охопила весь світ сьогодні. Життя за таких умов стане новою нормою для всіх, консульства, посольства, міжнародні організації не виняток. Також вона підводить до переосмислення дипломатії та іï ролі в роботі міжнародних відносин, в їх небезпечній діяльності, міжнародній підтримці та міжнародної взаємодопомоги. У міжнародній практиці набуває великого значення з кожним днем використання діджиталізації, соціальних платформ, відеоконференцій, які вже увійшли як альтернативний спосіб ведення міжнародної діяльності. Дипломатія буде переходити у цифровий формат і нині набуває ефективнішого значення в роботі посольств. Мета статті полягає у вивченні та аналізі роботи дипломатії та міжнародних відносин у період пандемії COVID-19, їх труднощі у цей період, наслідки та об'єднання зусиль, обмін передовим досвідом перед новітніми викликами соціуму. Розкрито методологічні та методичні підходи до вивчення проблем дипломатії та міжнародних відносин в період пандемії, їх роль та шляхи протидії розповсюдження COVID-19, ефективна міжурядова взаємодія. Боротьба проти пандемії досі триває і в Україні, усі посольства і консульства, а також міжнародні організації відіграють важливу роль у цій боротьбі, яка змушує адаптуватися до нових реалій і показує, наскільки важкою, але вкрай необхідною, є робота дипломатів у даний час.

Ключові слова: пандемія; пандемія COVID-19; дипломатія; консульська допомога; міжнародні відносини; діджиталізація; цифрова дипломатія. 
Shevel Inna, Candidate of Sociological Sciences, Associate Professor, Kyiv National University of Culture and Arts, Kyiv, Ukraine

\section{Diplomacy During the COVID-19 Pandemic - Its Role and Consequences in the Field of Diplomacy and International Relations}

The article is about the pandemic that has swept the whole world today. Life in a pandemic will become a new norm for everyone, consulates, and embassies, international organizations are no exception. It also leads to a rethinking of diplomacy and it in the work of international relations, in their dangerous activities, international support and international mutual assistance. In international practice, the use of digitalization, social platforms, video conferencing, which is already becoming an alternative way of conducting international activity, is becoming increasingly important. Diplomacy will move to a digital format and this is now gaining more effective importance in the work of embassies. The purpose of the article is to study and analyze the work of diplomacy and international relations during the COVID-19 pandemic, their difficulties during this period, the consequences and joining of efforts, the exchange of best practices in the face of new challenges to society. The methodological and methodological approaches to studying the problems of diplomacy and international relations during a pandemic, their role and ways of countering the spread of COVID-19, effective intergovernmental interaction are disclosed. The fight against the pandemic is still ongoing in Ukraine, all embassies and consulates, international organizations play the most important role, which forces us to adapt to new realities and shows how difficult, but extremely necessary, the work of diplomats is now.

Key words: pandemic; COVID-19 epidemic; diplomacy; consular assistance; international relations; digitalization; digital diplomacy.

Шевель Инна Петровна, кандидат социологических наук, доцент, Киевский национальный университет культуры и искусств, г. Киев, Украина

\section{Дипломатия во время пандемии COVID-19: ее роль и последствия в сфере дипломатии и международных отношений}

Статья посвящена пандемии, которая охватила весь мир сегодня. Жизнь в условиях пандемии станет новой нормой для всех, консульства, посольства, международные организации не исключение. Также она подводит к переосмыслению дипломатии и ее роли в работе международных отношений, в их опасной деятельности, международной поддержке и международной взаимопомощи. В международной практике приобретает большое значение использование диджитализации, социальных платформ, видеоконференций, которые уже вошли как альтернативный способ ведения международной деятельности. Дипломатия будет переходить на цифровой формат и это в настоящее время приобретает более эффективное значение в работе посольств. 
Цель статьи заключается в изучении и анализе работы дипломатии и международных отношений в период пандемия COVID-19, их трудности в этот период, последствия и объединение усилий, обмен передовым опытом перед новыми вызовами социума. Раскрыты методологические и методические подходы к изучению проблем дипломатии и международных отношений в период пандемии, их роль и пути противодействия распространению COVID-19, эффективное межправительственное взаимодействие. Борьба за пандемией до сих пор продолжается и в Украине, все посольства и консульства, а так же международные организации играют самую важную роль в этой борьбе, которая заставляет адаптироваться к новым реалиям и показывает, насколько тяжелой, но крайне необходимой, является работа дипломатов в настоящее время.

Ключевые слова: пандемия; эпидемия COVID-19; дипломатия; консульская помощь; международные отношения; диджитализация; цифровая дипломатия.

\section{Вступ}

Важливим викликом сьогодення $є$ пандемія COVID-19. Українське суспільство зіштовхнулося 3 багатьма глобальними проблемами під час пандемії. Влада запроваджує карантинні обмеження, носіння масок, користування дезінфекторами, дотримання дистанції. 3 боку державних органів $\epsilon$ повне і належне розуміння ситуації, вони плідно працюють з дипломатичними місіями, які знаходяться на території України, стосовно поставок гуманітарних вантажів та професійної медичної, гуманітарної допомоги.

\section{Аналіз останніх досліджень і публікацій}

Серед учених у галузі міжнародних відносин, соціології, соціофілософії можна відзначити праці С. Гантінгтона, Г. В.Ф. Гегеля, Е. Дж. Бека, Д. Белл, Ф. Джордж, Дж. Мартин, А. Турен. Б. Черкаський, С. Шах, які вивчають поняття «пандемія» в історичному значення стосовно цивілізаційного, порівняльного та компаративного боку. У своїх дослідженнях і публікаціях вони висловлюють свої думки щодо того, що у сучасному світі пандемії виникають внаслідок техногенного втручання людства у серце природи.

\section{Формулювання цілей статті}

Згідно поставленої задачі автор в своєму дослідженні показує розвиток та пошук нових ідей, методів і підходів, які нині поєднуються з дипломатичними практиками.

\section{Виклад основного матеріалу дослідження}

Нині весь світ стоїть перед викликом пандемії COVID-19. У глобалізаційному світі загальмовано всі процеси і слід налаштовуватися до нових альтернативних сценаріїв. Дотепер усі країни вимушені піти на ізоляцію і ці норми завдають потужний удар по економіці всієї планети. Вірус стрімко 
поширюється, збільшуються показники захворюваності та смертності, весь глобалізаційний світ не втрачає надії на вирішення цієї проблеми за допомогою вакцини від компаній Pfizer/BioNTech.

В Україні з кожним днем все гірше складається ситуація і стають червоними зонами майже всі території, зокрема і збройних конфліктів, це призводить до величезних збитків в економіці та збільшення росту безробіття. Населення країни занепокоєне своїми фінансовими труднощами у цей період більше, аніж стан пандемії. Соціально-економічний сегмент уже на декілька років вперед має зміни в показниках, які в подальшому можуть створювати проблеми підприємствам.

Багато галузей суспільства перейшли на оцифрування своєї діяльності, на інтернет-послуги, вони знайшли нішу виживання під час пандемії, зуміли перейти на онлайн режим, швидко перетрансформуватися і вийти 3 офлайн формату. На часі це допомагає дотримуватися всіх норм безпеки у запобіганні поширення вірусу та використовувати альтернативні способи проведення робочих переговорів.

В умовах пандемії стає актуальним завдання швидкого реагування, прийняття нестандартного рішення, здатність швидко реагувати на ситуації, які відбуваються в країні. Люди майже навчилися жити й існувати за карантинних умов, що стає новою нормою життя.

Пандемія COVID-19 стала провідним каталізатором до суспільних змін. Дипломатія у цей період повинна зберегти свій особливий статус і виконувати свою роботу, тому дипломатія швидко перейшла на цифрову, де онлайнплатформи стали основним джерелом спілкування і вирішення важливих питань, інструментом міжнародної взаємодії і швидкого реагування на зміни в соціумі. Альтернативним способом проведення міжнародних зустрічей стала відеоконференція (Diplomacy without Borders, 2020).

Під час пандемії в онлайн-дипломатії велика робота приділялася тому, щоб зберегти рівень довіри серед країн та їх лідерів. Рішення треба приймати негайно, часу мало, а інформації недостатньо, тому велика відповідальність лежить саме на організації онлайн-комунікації на міжнародному рівні. Однак, традиційна дипломатія не зникне, але дипломатам, які можуть приймати рішення в період діджиталізації, буде легше працювати.

Під час пандемії долучилися до вирішення проблем боротьби з COVID-19 багато посольств, консульських служб і міжнародних організацій. Україна отримала гуманітарну підтримку від багатьох країн світу: Азербайджанської Республіки, Естонської Республіки, Республіки Індії, Австрійської Республіки, Китайської Народної Республіки, Держави Катар, Литовської Республіки, Товариства Червоного Хреста в Україні, ОАЕ, Малайзї̈, Князівства Ліхтенштейна, Республіки Польща, Італійської Республіки, Республіки Туреччини, Японії, 
Швейцарської Конфедерації, Республіки Кореї, Королівства Норвегії, США. Сама підтримка складалася 3 різних видів матеріальної допомоги, таких як: медичні маски, безконтактні термометри, дезинфікатори, захисні комбінезони, апарати штучної вентиляції легень, тестові системи, захисні рукавички та грошова допомога окремих держав (США - 1 млн дол, Республіка Польща 200 тис. євро, Республіка Корея 700 тис. євро, Королівство Норвегії 14,5 млн євро), гроші були переведені в Об'єднаний фонд гуманітарної допомоги Україні через ООН на боротьбу з пандемією, підтримці Національної служби здоров'я України в боротьбі з пандемією. Італійська Республіка допомогла отримати дорогоцінний досвід нашим лікарям, оволодіти методами лікування в боротьбі з COVID-19 (Diplomacy without Borders, 2020).

Для полегшення дипломатичної комунікації створювалися онлайнмайданчики для спілкування, але вони мали недоліки: по-перше, неможливо через онлайн досягти компромісу у рішеннях, висловити конфіденційну інформацію, зберегти таємницю переговорів, але наразі головні питання вирішуються і технічні засоби не перешкоджають імпульсу зустрічі.

Разом із іншими країнами світу Україна теж запроваджує різні види жорстких заходів для запобігання поширення коронавірусу, але вони спричиняють соціальну напруженість серед населення з боку економічного сектору, яка набуває екзистенціального нерву саме у горизонті опозиції «здоров'я/хвороба», оскільки пандемія ставить людину на межу життя та смерті (Shakh, 2016).

За даними проведених Східноєвропейським національним університетом імені Лесі Українки соціологічних опитувань, у відповідь на питання чи слідкують респонденти за новинами про пандемію коронавірусу у світі і в Україні, позитивно відповіли 85 \%, негативно - 15 \%. Це є свідченням того, що ситуація в країні напружена та емоційно-нестабільна (Kuzmuk, 2020).

Але в боротьбі 3 пандемією треба дотримуватися певних правил. Глобальні проблем світу показані з позиції антисистеми або системи, яка має негативну базу системності у структурних складових, культурних та генетичних підгрунтях, її концептуальне бачення щодо дослідження пандемії встановлюють такі принципи: історичність, комплементарність, компаративність (Lukanova, 2019).

Під час карантинних умов з'являються критика та спірні моменти щодо запровадження дистанційного навчання в освітніх закладах. Однак, це не змусило освітян відмовитися від традиційного навчання, але дозволило поступово перейти до альтернативної змішаної системи навчання. Протягом усього карантину все ж освітні заклади зуміли налаштуватися на дистанційне навчання, нова хвиля розвитку і оволодіння соціальними платформи стали невід'ємною складовою в житті населення всього світу. 
Також до дистанційної роботи та навчання долучилася і дипломатія. 3'явилося сучасне поняття «Zoom-етикет», відповідно до якого під час відеоконференцій потрібно виключати мікрофон, не створювати зайвий шум, не виходити на зв'язок неохайним, не одягненим за правилами тощо. Стали нормою різні нові види привітань, наприклад, ліктями, кулачками та ін. Пандемія запровадила і дрес код в одязі: маски стали невід'ємною частиною гардеробу, їх стали носити в тон одягу, перетворили на дизайнерські тренди, також увійшло в моду носіння красивих рукавичок для жінок. Це підхопили не тільки дипломати, відомі політичні діячі, спортсмени, актори, а й пересічні громадяни. Також ми можемо спостерігати на телебаченні в різних шоупрограмах, що всі глядачі одягнені в маски під логотип передачі, це теж один із етикетних прийомів під час пандемії, «Zoom-дипломатія» запропонована дипломатичною академією України імені Геннадія Удовенка, для професійної підготовки в академії, для швидкого пристосування до нових інструментів дистанційної роботи в форматі міжнародної взаємодії (Diplomacy without Borders, 2020).

За інформацією соціологів Східноєвропейського національного університету імені Лесі Українки 54,9\% опитаних продовжують навчатися та працювати дистанційно; 8,8\% - у пошуках можливості для підробітку, оскільки мають фінансові труднощі; $30,1 \%$ знаходиться постійно у соціальних мережах, а про саморозвиток дбають під час ізоляції $25,7 \%$ респондентів (Kuzmuk, 2020).

На сьогоднішній день небагато праць, які досліджують поняття «пандемія». Будь-який об'єкт вивчення та проблема його виникнення повинна пройти повноцінний розгляд за розробленою методологією дослідження. Це поняття носить дисциплінарний характер і має поєднання у вивченні в різних галузях наукового, соціально-філософського знання. Чому слід починати 3 соціально-філософського вектора? Тому, що пандемія - це глобальна проблема світу. Вона впливає на розвиток історії суспільства, людину, порушує класичні норми-системи і стає антисистемою в соціумі. У цивілізаційному підгрунті продемонстровано, що, з одного боку, людство, довкілля - це єдина система, а з іншого, - це постійна суперечка, компроміс не знаходиться, у результаті чого виникають різноманітні глобальні проблеми, однією 3 яких $€$ пандемія (Lukanova, 2019).

Наукове вирішення цієї проблеми $є$ викликом сьогодення. Треба починати з методологічної сторони, тому що методологія базується на певних принципах, які задаються методами дослідження. Саме з боку методології існує ключовий принцип наукового значення феномену пандемії, іï історичне буття, компаративність. Це порівняння певних методологічних процедур, які містять у собі певний евристичний потенціал, про який показано у працях С. Гантінгтона 
(Huntington, 2004), Г.В.Ф.Гегеля (Hegel, 1974). Пандемія ставить межі для людини між життям і смертю і це призводить її в нервовий стан. Відбувається велика нерівновага у свідомості людини до позиції понять «здорова людина» і «хвора людина», між якими відбуваються суперечності, які призводять до різних глобальних проблем і пандемії в тому числі (Lukanova, 2019).

Наостанок можна навести слова глави Бюро Всесвітньої Організації охорони здоров'я в Україні Ярно Хабіхта: «Важливо пам'ятати, що прості профілактичні засоби й розважливе планування можуть мати величезне значення. Якщо діяти негайно, це допоможе захистити ваших колег, ваші родини та вас самих». Ці маленькі практичні рекомендації слід сприймати як поштовх до подолання пандемії, після чого настане «нова нормальність» в дипломатії та міжнародних організаціях, буде відновлене соціально-економічного життя (Diplomacy without Borders, 2020).

\section{Висновки}

Отже, підсумовуючи вищесказане, можна стверджувати, що вивчення пандемії як соціального явища, поки що, найбільш ефективним може бути-за допомогою порівняльного методу. Пандемія показала вразливість усіх країн і тому у світі створюється тренд на об'єднання зусиль до відкритої політики в міжнародних відносинах (але відповідно до державно-національних інтересів кожної країни), на створення нової системи взаємодії, та співпраці відповідно до нових соціальних реалій.

\section{References:}

1. Diplomacy without Borders. (2020). Kyiv: LLC Convey Print.

2. Hegel, G. W. F. (1974). Entsiklopediya filosofskikh nauk [Encyclopedia of philosophical sciences]. Nauka logiki [Science of Logics], Vol. 1. Moscow: Mysl'.

3. Huntington, S. (2004). Politicheskii poryadok $v$ menyayushchikhsya obshchestvakh [Political order in changing societies]. Moscow: Progress-Traditsiya.

4. Kuzmuk, O. (2020). 'Sotsiolohy PRO zhyttia v umovakh karantynu' [Sociologists about life in quarantine]. Skhidnoievropeiskyi natsionalnyi universytet imeni Lesi Ukrainky [Lesia Ukrainka East European National University], [online]. Available at: https://eenu.edu.ua/uk/articles/sociologi-pro-zhittya-v-umovahkarantinu.

5. Lukanova, V.V. (2019). Fenomen pandemii: pidgruntia, sutnist, dynamika (sotsialno-filosofskyi analiz) [Pandemic phenomenon: background, essence, dynamics (socio-philosophicalanalysis)], [online]. D.Ed. Oles Honchar Dnipro National University.

Available at: https://chtyvo.org.ua/authors/Lukanova_Viktoriia/Fenomen_pandemii_pidgruntia_su tnist_dynamika_sotsialno-filosofskyi_analiz//. 
6. Shakh, S. (2016). Pandemiya. Vsemirnaya istoriya smertel'nykh virusov [Pandemic: History of deadly viruses]. Moscow: Alpina Digital.

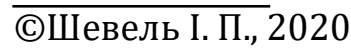

